\title{
Functional Factors on Compliance Drugs Consumption in Diabetes Melitus Patients Related to Periodontal Health
}

\author{
Retno Palupi ${ }^{1}$, Titiek Berniyanti ${ }^{1,}$ Ridho Akbar ${ }^{2}$, Taufan Bramantoro ${ }^{1}$, Ninuk Hariyani', \\ Aulia Ramadhani ${ }^{1}$, Sarah Fitria Romadhoni ${ }^{1}$ \\ ${ }^{1}$ Department of Dental Public Health, Faculty of Dental Medicine, Universitas Airlangga, \\ ${ }^{2}$ Graduate Student of Dental Health Science, Faculty of Dental Medicine, Universitas Airlangga
}

\begin{abstract}
Background: Tambakrejo Health Center is one of the public health services in Surabaya that provides integrated dental and oral health services. As many as $69 \%$ of the community in health center working area were exposed to periodontal problems, and around $18 \%$ suffered from diabetes mellitus.

Objective: This study aimed to identify the factors that play a role in compliance with drug consumption in patients with diabetes mellitus associated with periodontal tissue in the working area of Tambakrejo health center in Surabaya.

Methods: This was an observational analytic study with cross sectional method. The study sample was 60 people with diabetes mellitus selected with a random sampling technique. Respondents filled out questionnaires to measure patients' perceptions, knowledge, attitudes, and actions about drugs, diabetes mellitus, periodontal health, and the level of compliance with drug consumption. The sample oral hygiene status was determined using the Russell Index.
\end{abstract}

Results: The data obtained showed that as many as $67 \%$ of the samples had low level of compliance. Whereas, $20 \%$ of the sample had moderate level of compliance. Only $13 \%$ of the sample had high level of adherence.

Conclusion: There was a significant correlation between the level of compliance of patients taking antidiabetic drugs and the periodontal health.

Keywords: Diabetes mellitus, patient compliance, Patient medication knowledge, periodontitis

\section{Introduction}

The prevalence of diabetes globally affected around $9 \%$ of adults aged 18 years and over in 2014. The World Health Organization (WHO) projects that diabetes will be one of the main causes of death because the number has increased. Indonesia is the 4th largest country with a growth of $152 \%$ of diabetics or from $8,426,000$ people in 2000 to $21,257,000$ in $2030 .{ }^{1}$

\section{Corresponding author:}

Retno Palupi

Jl. Prof. Dr. Moestopo No. 47

Phone: (+6231) 5030255, 5020256

Facsimile numbers: (+6231) 5020256

E-mail: retno-p@fkg.unair.ac.id
According to Trekas (1984) in Tombokan et al (2005), the ability of DM patients to control their lives can affect the level of adherence. A person who is health-oriented tends to adopt all habits that can improve and restore his/her health. Non-compliance will be an obstacle to achieving treatment goals. This noncompliance can be overcome by providing counseling to people with Diabetes Mellitus and their families. ${ }^{2}$ According to Ajzen (2005), several factors that can influence medication compliance is the intention of the sufferer, which includes the attitude of the patient, support from the husband and the patient's belief in treatment. $^{3}$ 
According to Herlena and Widiyaningsih (2013), an attitude will not necessarily be realized in the form of an action. The realization of a positive attitude requires supporting factors or a possible condition. If all positive behaviors have been implemented, DM patient can be included in the group of DM patients with high compliance. An impact of compliance, one of which, is control of diabetes. The attitude of respondents which is not good is indicated by the attitude of respondents who do not support the treatment of DM. ${ }^{4}$

In the previous study on "Diabetes mellitus as a risk factor for periodontal problems in people aged $>20$ years in the working area of Tambakrejo Health Center in Surabaya 2017", one of the highest risk factors was found. The relationship between the level of compliance with drug consumption in people with diabetes mellitus and health status periodontal showed the prevalence of patients who do not routinely consume drugs by $48 \%$. The regularity of treatment can be supported by family support, education, patients' knowledge about the disease and the medication they consume (Laoh et al., 2013). ${ }^{5}$

Based on what has been described above, researchers are interested in conducting research to find out what factors influence compliance with drug consumption in patients with diabetes mellitus associated with periodontal tissue in the working area of Tambakrejo Health Center, Surabaya.

\section{Subjects and Method}

This was an observational analytic study with cross sectional method. This study was carried out in Tambakrejo Health Center working area, Surabaya. The population in this study were 60 people age 45-60 years old with diabetes mellitus who were in the Tambakrejo Health Center working area as samples obtained through random sampling techniques.

The independent variable in this study was compliance to drug consumption in people with diabetes mellitus. The dependent variable in this study was periodontal tissue. Data collected by questionaire and intra oral examination for checking the periodontal health with Russell Index. Data were analyzed by Correlation Test and significance with $95 \%$ confidence intervals. To identify risk factors, Prevalence Ratio, Relative risk, a significance were calculated, and correlation with linear regression test was carried out so that the level of possible risk of each variable studied on the level of compliance taking medication could be estimated.

\section{Findings:}

Table 1. Analysis of periodontal health data with the Russell index

\begin{tabular}{|l|l|l|}
\hline Variable & $\mathbf{n}$ & $\mathbf{\%}$ \\
\hline Clinically normal & & \\
Simple gingivitis & 1 & 1.7 \\
Beginning destructive & 0 & 0 \\
periodontal disease & 1 & 1.7 \\
Estabilished destructive & 37 & 61.6 \\
periodontal disease & 21 & 35 \\
Terminal disease & $\mathbf{6 0}$ & $\mathbf{1 0 0}$ \\
Total & & \\
\hline
\end{tabular}

Based on Table 1, the highest percentage is found in respondents who have the Russell index in the form of Established Destructive Periodontal Disease, which is $61.7 \%$. Then, it was followed by Terminal Disease, which was equal to $35 \%$. The third were Clinically normal and the Beginning Destructive Periodontal Disease, which were $1.7 \%$ respectively, and the last was Simple Gingivitis with a percentage of $0 \%$.

Table 2. Correlation and significance of risk factor variables with the level of respondents' compliance to antidiabetic treatment

\begin{tabular}{|l|l|l|}
\hline & $\begin{array}{l}\text { Compliance of } \\
\text { patients in taking } \\
\text { medication }\end{array}$ & Russell Index \\
\hline Spearman's rho & $\mathbf{0 . 2 6 5}$ & $\mathbf{0 . 0 4 1}$ \\
\hline
\end{tabular}

Based on Table 2, there is a correlation between the level of adherence of patients taking antidiabetic drugs and the periodontal health level as measured by the Russel Index with $\alpha$ of $0.041<0.05$ and the correlation index of 0.265 .

The results of the study on patients' knowledge of diabetes drugs were obtained with a low category of $30 \%$, moderate of $46.7 \%$ and high of $28.3 \%$ of respondents. Drug knowledge of these patients was influenced by several factors, especially the level of education of patients, explanations and how the explanations received by patients and how the role of health care workers in explaining to these patients. This is in accordance with research by Dunning and Manias (2005) in patients 
with diabetes mellitus in Australia in which there is a close relationship between the level of education and "training" received by patients on how patients act in dealing with diabetes and the reasons patients sometimes only take medication if told to do so. ${ }^{6}$

Based on the results of the study with the risk factors for knowledge of patients with diabetes mellitus, the highest percentage was found in respondents who had high or good knowledge of diabetes mellitus by $55 \%$, then $35 \%$ of respondents had moderate level of knowledge of diabetes mellitus, and $10 \%$ of respondents had low level of knowledge. This is not in accordance with studies that stated that patients with better knowledge of diabetes mellitus have a good level of compliance to taking drugs. This can happen because the level of adherence to taking antidiabetic drugs is not only influenced by knowledge about antidiabetic drugs, but also by other factors, such as communication with the family and health care workers. ${ }^{7}$

From the results of the research on the patients' knowledge regarding the role of health services, the results showed that the knowledge of the general practitioners and their suggestion to refer to patients with diabetes mellitus to the dentist had an effect on the level of compliance to taking patient medication. ${ }^{8}$

Patient attitudes towards antidiabetic drugs found $85 \%$ of respondent's were high or good attitudes towards anti-diabetic drugs, $15 \%$ of patients were on anti-diabetic drugs and no respondents had low or bad attitude towards anti-diabetic drugs. Most patients wanted to get well soon from their diabetes and thought that anti-diabetic drugs were important for consumption, but it was not comparable to the actions they took on antidiabetic drugs and diabetic control, which was consistent with research in the third world where most population have low knowledge but have high attitude to recover, but it is not supported by adequate facilities. ${ }^{9}$

From the results of the study, $93.3 \%$ of respondents had good attitude towards diabetes. No respondent had poor attitude in dealing with diabetes. This showed that even though the patients' attitude was good towards diabetes mellitus, it did not affect the level of awareness of patients in taking anti-diabetic drugs. This is the same as expressed by the study that even patients have good attitude, if it is not supported by adequate knowledge, the output of the patients' actions remains poor. ${ }^{9}$
From the results of this study, most respondents $(80 \%)$ had moderate/normal attitude towards periodontal health. There is a difference between attitudes and knowledge of diabetes and periodontal disease. This is different from research in developed countries. The average patients have knowledge and good attitudes towards the health of the body, including the oral cavity and good correlation due to good health service factors, the government that cares about the community, and affordable and even free health services because they are covered by insurance. ${ }^{6}$

From the results of the research respondents' perceptions of antidiabetic drugs, it was found high/ good perception rate of patients on anti-diabetic drugs by $81.7 \%$, and no patients had a low/poor perception of anti-diabetic drugs. This is because the price of diabetic medicine is relatively cheap and even free and can be obtained easily by patients both at the nearest pharmacy and at the health centre. Patients also feel that the consumption of drugs does not disturb their diet. The dosage is also sufficient for patients, it is not difficult for respondents to drink. ${ }^{6}$

From the results of research with risk factors for patient perceptions of health services, it was found that the highest percentage was in respondents with moderate perceptions of health services (51.7\%), followed by high perceptions of health services $(30 \%)$, and low perception of health services $(18.3 \%)$. Good interpersonal relationships will make patients feel a good appreciation too, which ultimately makes them happy, even satisfied with the service received. The satisfaction that remains within them will shape the perception that health services have certain quality. ${ }^{10}$

From the results of the study of patient perceptions of the duration of therapy, data obtained showed that $53 \%$ of patients answered yes to the question "Tired of having taken too long medicine", in which it was negative. Furthermore, $47 \%$ of patients answered no to the statement in which it was positive. This was due to many factors, such as the data distribution which was not good or because there were not many samples. Respondents tended to be bored because the use of drugs that lasted long and continuously. This research was in line with the research results. ${ }^{2}$

Data from the research on the patients' actions on antidiabetic drugs found high or good level of patient 
action on antidiabetic drugs as much as $61.67 \%$. Whereas, $28.3 \%$ of respondents had low or poor levels of action against antidiabetic drugs, and $10 \%$ of respondents had moderate level of action on antidiabetic drugs. This illustrates that the patients' actions on antidiabetic drugs affected compliance to taking anti-diabetic drugs. The patients' actions are included in understanding the doses, complications, and side effects of the drug. If the patients have good understanding and action, they will tend to be more responsible in the routine of taking medicine. ${ }^{11}$

Data from research on the actions of patients on diabetes mellitus showed the level of action of patients which was high or good for diabetes mellitus by $71.67 \%$, the level of patient action was low for diabetes mellitus by $18.3 \%$, and the level of action of patients which was moderate on diabetes mellitus by $10 \%$. This illustrates the relationship between actions against diabetes mellitus with compliance to taking diabetes mellitus medication. With good actions from patients, such as routinely doing blood sugar checks and control in the doctor, patients will tend to be more obedient in taking antidiabetic drugs. ${ }^{7}$

The results of the study also discussed the actions of patients on periodontal disease and found that respondents had moderate actions on periodontal health (71.7\%), respondents had high actions on periodontal health (16.6\%), and respondents had low actions on periodontal health (11.7\%). Patients who had low knowledge and poor attitude towards their periodic health also had poor or inadequate actions to keep their periodic health, such as never visiting a dentist, not regularly toothbrushing, doing toothbrushing in wrong way, and never using dental floss..$^{12,13}$

The results of statistical tests showed high and significant correlation between the Russell index which describes the periodontal condition and the Patient Compliance Level for consumption of antidiabetic drugs. There was correlation between the level of compliance of patients taking antidiabetic drugs and the periodontal health measured by the Russell Index with $\alpha$ of $0.041<0.05$ and correlation index of 0.265 .

\section{Conclusion}

There was close relationship between the level of compliance of respondents to the treatment of diabetes with the level of periodontal health (Russell Index).

Conflict of Interest: Nil
Source of Funding: Self funding

Ethical Clearance: This research is a branch of the main research entitled: Overview of Denture Demand of Elderly in Nursing Home around Public Health Centre.

\section{Conflicting Interest: None.}

Acknowledgement: Department of Dental Public Health, Faculty of Dental Medicine, Universitas Airlangga, Surabaya, Indonesia.

\section{References}

1. World Health Organization. Fact Sheets Of Diabetes Media Center [Online]. 2015 [Cited 2018 Dec]. Available from http://www.who.int/mediacenter/ factsheets/fs312/en/.

2. Tombokan V, AJM Rattu, dan Ch. R Tilaar. Factors Associated with Treatment Compliance with Diabetes Mellitus Patients in Family Physics Practices in Tomohon City. Jurnal Ilmu Kesehatan Masyarakat Unsrat. 2015;5(1)

3. Ajzen I. Attitudes, Personality, and Behavior. New York : Open University Press. 2005.

4. Herlena EP, Widiyaningsih. Relationship Between Knowledge and Attitudes of Patients with Diabetes Mellitus With Compliance with Diabetes Mellitus Diet in Public Hospital, Parikesit East Kalimantan. Jurnal Keperawatan Medical Bedah. 2014;1(1)

5. Laoh et al. Relationship between neck circumference and obesity in students of the Sam Ratulangi University medical school. Jurnal: e - Biomedik. 2013;1(2):901-906.

6. Dunning T, Manias E. Medication knowledge and self-management by people with type 2 diabetes. Australian Journal of Advanced Nursing. 2005;23(1):7

7. Yang H, Gao J, Ren L, Li S, Chen Z, Huang J, Zhu S, Pan, Z. Association between Knowledge-AttitudePractices and Control of Blood Glucose, Blood Pressure, and Blood Lipids in Patients with Type 2 Diabetes in Shanghai, China: A Cross-Sectional Study. Journal of Diabetes Research. 2017:1-9.

8. Shanmukappa SM, Nadig P, Puttannavar R, Ambareen Z, Gowda TM, Mehta, DS. Knowledge, Attitude, and Awareness among Diabetic Patients in Davangere about the Association between Diabetes and Periodontal Disease. Journal of International Society of Preventive \& Community Dentistry. 
2017;7(6):381-388.

9. Medhi B, Puri A, Upadhyay S, Kaman L. Topical application of honey in the treatment of wound healing: a metaanalysis. JK Science. 2008;4(10): 166-9.

10. Medhi B, Puri A, Upadhyay S, Kaman L. Topical application of honey in the treatment of wound healing: a metaanalysis. JK Science. 2010;4(10):1669.

11. Federman DG, Kirsner RS. The Primary care physician and the treatment of patients with skin disorders. Dermatologic Clinics. 2000;18:215-221.

12. Martha, E. Kresno, S. Metodologi Penelitian Kualitatif untuk Bidang Kesehatan. Jakarta: Rajawali Pers; 2016.

13. Kekenusa JS, et al. Analysis of the Relationship Between Age and Family History of DM Patients with the Occurrence of Type 2 DM in Outpatients in the Internal Medicine Polyclinic, RSUP Prof. Dr. R.D Kandou Manado Manado: Fakultas Kesehatan Masyarakat Universitas Sam Ratulangi Manado; 2013. 